\title{
The Conflict between the Spiritual and the Sensual Dimension in Kate Chopin's Short Stories
}

\author{
Florinda Boriçi \\ Ph.D. Candidate \\ Professor at Tirana University, Albania
}

\section{Doi:10.5901/mjss.2013.v4n9p314}

\section{Abstract}

\begin{abstract}
The aim of this paper is to analyze the conflict between the spiritual and the sensual dimension in Kate Chopin's short stories, specifically in "Two Portraits", "Lilacs" and "A Vocation and a Voice". Kate Chopin is the author of some of the boldest and best stories written in America before the 1960s. She set most of her stories in late nineteenth-century Louisiana and portrayed characters from all social classes of her time and place. Her stories explore the relationships between these various classes and especially, relationships between men and women. In her stories are treated all sorts of taboo subjects such as miscegenation, divorce, and even female sexuality. Chopin concentrated on the immutable impulses of love and sex and was deeply influenced by Walt Whitman and Guy de Maupassant in this regard. She was the first woman writer in her country to accept passion as a legitimate subject for serious, outspoken fiction. Revolting against tradition and authority; with a daring which we can only fathom today; with an uncompromising honesty and no trace of sensationalism, she undertook to give the unsparing truth about women's submerged life. Kate Chopin is considered today by many critics as a prophet of the twentieth century feminism.
\end{abstract}

Kate Chopin (the name is pronounced in the French way) became known to the American reading public in the early 1890's through her Louisiana tales in Vogue, the Century, and the Atlantic. She was the daughter of an Irish immigrant father and a St. Louis mother. Kate Chopin was educated in a Roman Catholic convent school where she was exposed not only to catholic teachings but also to a French emphasis on intellectual vigor. Kate became thoughtful and openeyed, an omnivorous reader and an inquisitive observer. She was greatly interested in the careers of writers. Chopin admired and translated Maupassant, and she combined in her excellent style French limpidity with Irish grace. At the age of twenty she married a French Creole and went to live in Louisiana. (The Creoles were pure blooded descendants of French and Spanish colonists. Their society was more European than American, with more relaxed canons of civility and an open sensuality, even though discrete.) In the picturesque and cosmopolitan city of New Orleans she became acquainted with the Cane River Creoles, Negroes and Acadians or Cajuns. (The Cajuns were descendants of French settlers whom the British had expelled from Nova Scotia in the eighteenth century.) The Chopin's family plantation was later to provide the setting for Kate Chopin's first novel. The thirty-nine year old Kate was a very mature woman when she turned to writing in earnest and her attitudes are markedly consistent through practically her whole oeuvre.

Many of the views which informed Kate Chopin's fiction from the start are suggested in her essays of the middle 1890s. She insisted here that no author can be true to life who refuses to pluck from the Darwinian tree of knowledge and to see human existence in its true meaning. To her nature was amoral, playing with man, and morality was man-made and relative. In her view, man is basically the same today as he has ever been, that is, ruled by imperative, immutably selfish drives. To her art was incompatible with a thesis and with a zeal for reform. "Human impulses do not change" Kate Chopin reported, and when Aeschylus is true today, one reason is that he does not deal with local color or with social problems which by their very nature are mutable." (Seyerster.ed., The Complete Works of Kate Chopin [CW], 2006, p.693) As for herself, Kate Chopin concentrated on the immutable impulses of sex and Love, and Whitman and Maupassant were two of the authors who spoke most deeply to her, probably because they acknowledged the existence of Eros and because they had helped to extend the literary limits to the treatment of sex. Though she leaned to the French school, she believed that American writers with their "wider and more variegated field of observation" might equal and perhaps even surpass the French authors, "were it not that the limitations imposed upon their art by their environment hamper a full and spontaneous expression". (Seyersted, 1980, p.89)

Kate Chopin reached the highest point of her public success in 1894 when Bayou Folk, her first collection of short stories came out. She was welcomed in more than a hundred press notices as a distinguished local colorist. Local Color is a term applied to fiction that came to prominence in the late 19th century and was devoted to capturing the features 
and peculiarities of a particular locality and its inhabitants- their distinctive dialect, history and customs. A large number of Kate Chopin's works are set in Natchitoches, which she made her special literary province, and inevitably they have many traits in common with the local color literature of her time. Discretely, yet forcefully, she evokes her particular locality with the enchanting Cane River atmosphere, the quaint idioms, and the charming idiosyncrasies of the Natchitoches people. But even though she concentrated on what was then a distant, exotic community, she never emphasized the strange or remote; and though like George W. Cable and Grace King she commanded a wealth of local material, she did not join them in focusing on old Creole days. She was concerned with the living present rather than the past, with universal rather than regional aspects of life. Kate Chopin's interest was not so much idyllic localism as what she termed in one of her essays "human existence in its subtle, complex, true meaning, stripped of the veil with witch ethical and conventional standards have draped it." (CW, 2006, p. 691)

The sudden national fame inspired Kate Chopin to write "The Story of an Hour", a most remarkable account of a woman who exclaims "Free! Free! Free!" (CW, 2006, p. 353) when she hears of her husband's sudden death. Her subsequent writings reflect an increasing self-confidence and daring. The reason why editors now turned down a number of her stories was very likely that her women became more passionate and emancipated. Her very first, Paula Von Stoltz of "Wiser Than a God", refuses the "labor of loving" (CW, 2006, p. 45) which a man wants to impose upon her, and becomes instead a famous pianist. In thus opposing the traditional female duties and limitations. She is a female who insists on the active transcendence of a subject rather than the passive immanence of an object, on an existentialist authenticity obtained through exerting a conscious choice, giving her own laws, and making herself her own destiny. Mildred Orme of "A Shameful Affair" is another illustration of this type of woman. She rejects the role of the passive, innocent party who makes no advances in sexual relations and demands instead the responsibility of an active subject. The new force which was freed in Kate Chopin through the success of Bayou Folk is seen particularly in her heroines who live out their strong impulses. Chopin saw and understood all aspects of the female psyche, and her particular interest was the woman's awakening to her true nature, whether traditional, emancipated, or a mixture of the two. In "Regret" she describes how the middle-aged Mamzelle Aurélie all of a sudden realizes what she has missed by not having children.

Kate Chopin is the author of some of the boldest and best stories written in America before the 1960s. In her stories are treated all sorts of taboo subjects such as miscegenation, alcohol, divorce, and even female sexuality. Of a particular importance in her stories is the treatment of the identity crises that both man and women face, the conflicts that rise between selfhood and sexual attraction. Three of the short stories where she deals with this conflict between the spiritual and the sensual dimension are "Two Portraits", "Lilacs" and "A Vocation and a Voice".

The short story "Two Portraits" was earlier given other titles by Chopin, at one time calling it "The Nun and the Wanton" and at another time "The Nun, the Wife and the Wanton" (CW, 2006, p. 1026). All three titles, of course suggest that the protagonist, Alberta, exists in an undivided state. Chopin first sketches the character of Alberta the Wanton, who becomes a prostitute at an early age, and she takes good care of her body "for she knows it will bring her love to squander and gold to squander". (CW, 2006, p. 463) Someone tells Alberta to save her gold, warning her that she will not always remain young and beautiful. But Alberta, like many Chopin characters, knows a way to escape that which she cannot face: "with death and oblivion always within reach" she need never fear the "degradation" of age and "ugliness". (CW, 2006, p. 463) Alberta the Wanton, possessing no spiritual dimension, can end her existence whenever the "ugliness" of age threatens "degradation". After completing her portrait of Alberta the Wanton, Chopin puts the same raw materials into a different environment and creates by contrast Alberta the Nun, who needs a physical dimension as badly as her twin needs a spiritual one. Whenever Alberta tries to experience God with her senses a mother figure tells her that one reaches God with the soul, not the body. This "holy woman" teaches Alberta "that the soul must be made perfect and the flesh subdued" (CW, 2006, p. 464).

Consequently, when this Alberta matures, she feels an overpowering impulse toward the spiritual; and so she enters the convent, where she sees "visions" that seem to be at least as sensual as they are spiritual. Their effects are described through such terms as "ecstasy", "roused", "awakened", "pressed her lips", "quivering contemplation", "abandon herself" and "swooned in rapture" (CW, 2006, p. 465-466). Thus Alberta the Nun with her attention riveted upon heaven, remains as pathetically unfulfilled as Alberta the Wanton, whose total existence centers upon the flash. Both lack a necessary dimension.

The short story "Lilacs" develops a similar theme to that of "Two Portraits", but here two different individuals embody the Wanton and the Nun and each comes to realize what her life lacks. The protagonist Mme. Adrienne Farival, represents the Wanton, although Chopin develops Adrienne's character more fully than Alberta's. Adrienne- an actress, singer, object of devotion to a series of man- lives an exciting life. But every spring when the lilacs first bloom, she goes 
to visit the convent where she once attended school. She arrives with an armload of lilacs and an expensive gift for the convent; and she remains for two weeks, her pleasure in the quiet peacefulness revealing that her worldly life lacks something important. Sister Agathe, that in this story represents the Nun, looks forward to Adrienne's visit one lilac-time to the next, declaring that "If you should once fail to come, it would be like spring coming without the sunshine or the song of birds" (CW, 2006, p. 358). Her joy at the light and life associated with Adrienne reveals the incompleteness of convent life.

But one spring Mother Superior, apparently having heard about Adrienne's worldly life, writes a cold message forbidding Adrienne to enter again the convent premises. When Adrienne arrives with her lilacs, a messenger silently hands her the letter and then closes the doors in her face. Consequently, Adrienne and Sister Agathe both suffer greatly. Each needs that brief but nourishing contact with the other's world to fill a bit of the void that exists inside herself.

The short story "A Vocation and a Voice" makes it clear that Chopin knew the strength of sexual attraction and the conflicts that rise between it and selfhood. And here in this short story it is shown from a masculine point of view. The story features a homeless, loveless, even nameless protagonist who is called only "the boy" until almost the end of the narrative. "A Vocation and a Voice" essentially tells the story of the boy's search for his own identity.

The boy one day decides to go along with a gipsy couple he encounters He enjoys camping out and contributes his share to the group's welfare by doing various chores. By calling him only "the boy," the narrator emphasizes his youthful innocence. And as the story unfolds, his namelessness poignantly emphasizes the universality of his experience- the loss of innocence and the accompanying search for place, love and knowledge of self. The boy finds a place with this make-shift family as they make their leisurely way southward. They stop for a month near a village, where the boy renews his close contact with the Catholic church. When Suzima and Gutro, the gipsy couple, decide to move at the end of a month, the village priest tries to get the boy to stay. But the boy refuses: "I got to go,' he murmured.... Yes, he wanted to lead an up-right, clean existence before God and man.... He liked the village, the people, the life which he had led there. Above all he likes the man whose kindly spirit had been moved to speak and act in his behalf. But the stars were beginning to shine and he thought of the still nights in the forest. A savage instinct stirred within him" (CW. 2006, p. 536). Perhaps the man is beginning to awaken within the boy.

Suzima often sings as the three walk along the road. "The boy thought he had never heard anything more beautiful than the full, free notes that came from her throat, filling the vast, woody temple with melody. It was always the same stately refrain from some remembered opera that she sang" (CW, 2006, p. 527). In fact, "the only stately refrain" (CW, 2006, p. 533) grows so familiar to the boy that he sometimes hears it in his dreams.

This idyllic existence continues until one day the boy happens upon Suzima bathing nude in a little stream. "He saw her as one sees an object in a flash from a dark sky- sharply, vividly. Her image, against the background of tender green, ate into his brain and into his flash with the fixedness and intensity of white hot iron". Afterward the woman at first acts "less kind" (CW, 2006, p. 539) to him, but they soon become lovers.

The sexual experience produces an immediate, dramatic effect: "A few days had wrought great changes with the boy. That which he had known before he now comprehended, and with comprehension sympathy awoke. He seemed to have been brought in touch with the universe of men and all things that live. He cared more than ever for the creeping and crawling things, for the beautiful voiceless life that met him at every turn;... that silently unfolded the mysterious, inevitable existence" (CW, 2006, p. 541). Thus the boy who began the story without place, love or knowledge of himself has found all three.

But inevitably his love for Suzima and his new comprehension of life soon make his place as "the boy" in this household untenable. A quarrel between Gutro and Suzima sets off the explosion: "Suddenly, the man, in a rage, turned to strike her with a halter that he held uplifted, but, quicker than he, the boy was ready with a pointed hunting knife that he seized from the ground" (CW, 2006, p. 542). Although the fracas causes no serious physical injuries, its results nevertheless reach far.

The boy thus encounters an abrupt challenge not only to his delicious new feeling of understanding and sympathy with all of life but even to his long-held concept of his own inner person: "He had always supposed that he could live in the world a blameless life... He had never dreamed of a devil lurking unknown to him, in his blood, that would someday blind him, disable his will and direct his hands to deeds of violence.... He felt as if he had encountered some hideous being with whom he was not acquainted and who had said to him: "I am yourself" (CW, 2006, p. 542) This new concept of himself he finds unbearable, and so he enters a monastery, the "Refuge"(CW, 2006, p.544), where he succeeds for years in hiding from "the devil lurking... in his blood."

At the refuge the boy acquires a new sense of who he is and, at last, even a name- brother Ludovic: "He often felt that he had been born anew, the day whereupon he had entered the gate of this holy refuge. That hideous, evil specter 
of himself lurking outside, ready at any moment to claim him should he venture within its reach, was, for a long time, a menace to him. But he had come to dread it no longer, secure in the promise of peace which his present life held out to him". (CW, 2006, p. 543-544)

Thus he comes to feel secure in his new place and in his knowledge of himself. Brother Ludovic has a great dream, to build a solid stone wall round the Refuge. He works feverishly at this task that will take a lifetime to complete. "He liked to picture himself an old man, grown feeble with age, living upon this peaceful summit all enclosed by the solid wall built with the strength of his youth and manhood". (CW, 2006, p. 544)

But he learns that this self-image, too, lacks completeness. One day while working on his wall, "Suddenly Brother Ludovic stopped, lifting his head with the mute quivering attention of some animal in the forest, startled at the scent of approaching danger.... The air was hot and heavy.... He could hear soft splashing at the pool. An image that had once been branded into his soul... unfolded before his vision with the poignancy of life" (CW, 2006, p. 545) These strong appeals to the senses of smell, sight, hearing and touch remind the reader that Brother Ludovic remains a physical being as well as a spiritual one. Then a distant sound draws nearer, and the images grow more sensual: "he had heard the voice of a woman singing the catchy refrain from an opera... The sound was faint and distant but it was approaching, coming nearer and nearer". Finally, the sexual magnetism overwhelms Brother Ludovic: "He was conscious of nothing in the world but the voice that was calling him and the cry of his own being that responded. Brother Ludovic bounded down from the wall and followed the voice of the woman". (CW, 2006, p. 546) Thus Brother Ludovic learns that he needs more from life than a secure place, even the "Refuge"; that nothing, not even rock walls, will contain the force of sexual attraction; and that he may never know fully that complex person who dwells within himself.

In conclusion in these three short stories "Two Portraits", "Lilacs" and "A Vocation and a Voice" Chopin shows that both the physical and the spiritual dimensions of life are important. And that man as well as women face identity crises and conflicts between the spiritual and the sensual dimension. Despite the distinctly masculine point of view in "A Vocation and a Voice", the boy exhibits universal, conflicting needs that transcend the limitations of gender. In Chopin's day society allowed, although it did not encourage, a writer to examine these human needs from the masculine point of view. But when the same author later offered in The Awakening a female character, Edna Pontellier, engaged in a similar struggle to find herself, the public and most literary critics ostracized Chopin and her works, bringing to a virtual conclusion her literary career.

\section{References}

Seyersted, Per, Kate Chopin: A Critical Biography (1980), Baton Rouge: Louisiana State University Press; Oslo: Universitetsforlaget Seyersted, Per, ed. The Complete Works of Kate Chopin (2006), Baton Rouge:Louisiana State University Press 